\title{
Study of therapeutic results, lymph node ratio, short-term and long-term complications of lateral lymph node dissection in rectal cancer patients
}

\author{
Habibollah Mahmoodzadeh ${ }^{1}$ (D), Ramesh Omranipour ${ }^{1}$ (D), Anahita Borjian ${ }^{1}$ (D), Mohammad Amin Borjian ${ }^{1}$ (D) \\ ${ }^{1}$ Tehran University of Medical Science, Cancer Institute, Tehran, Iran
}

\begin{abstract}
Objective: This study aimed to assess disease free survival, lymph node ratio (LNR) and complication rate among advanced mid to low rectal cancer patients (stage 2-3) who underwent total mesorectal excision (TME) and lateral lymph node dissection (LLND) at the Iran Cancer Institute in 2016-2018.

Material and Methods: The study was carried out on 32 patients treated by curative surgery and lateral lymph node dissection at the Iran Cancer Institute from 2016 March to 2018 March. Chi-square test was used to assess the distribution of dichotomous clinical outcomes by sex. We also used Breslow test in Kaplan-Meier approach to estimate 1-year disease free survival and corresponding 95\% confidence intervals (CI).

Results: Of the 279 dissected lymph nodes by TME, 42 nodes (in mesorectal) and of the 232 dissected lymph nodes by LLND, 7 nodes (in iliac, para-iliac and obturator) were positive for metastasis. Higher local recurrence was observed in men (three patients) compared to women (one patient) which was not statistically significant $(p=0.878)$. We also observed higher 1 -year disease free survival rate in women (1-year disease free survival=93.3\%) compared to men (1-year disease free survival= $82.4 \%$ ), which also was not statistically significant $(p=0.356)$. 1-year disease free survival rate in patient with negative lymph nodes was $95.5 \%$ while respective number in patients with positive lymph nodes was $70 \%(p=0.047)$.
\end{abstract}

Conclusion: TME with LLND could prolong survival and reduce local recurrence in patients with advanced low rectal cancer. However, large-scale clinical trials are required to evaluate such procedure as a standard in Iran.

Keywords: Rectal neoplasms, lymph node excision, survival, chemoradiotherapy

Cite this article as: Mahmoodzadeh $\mathrm{H}, \mathrm{Omranipour} \mathrm{R,} \mathrm{Bor-}$ jian A, Borjian MA. Study of therapeutic results, lymph node ratio, short-term and long-term complications of lateral lymph node dissection in rectal cancer patients. Turk J Surg 2020; 36 (2): 224-228.

\section{Corresponding Author}

Anahita Borjian

E-mail: anahitaborjian@yahoo..com

Received: 22.08.2019

Accepted: 30.12 .2019

Available Online Date: 08.06.2020

o Copyright 2020 by Turkish Surgical Society Available online at www.turkjsurg.com

DOI: 10.5578/turkjsurg.4593

\section{INTRODUCTION}

Total mesorectal excision (TME) is known as the standard treatment for advanced low rectal carcinoma. It is reported that adoption of TME could be of benefit for patients with low rectal carcinoma (1-3). TME could decrease local recurrence and increase survival. Previous studies have supported the effectiveness of TME. However, it is reported that $5-40 \%$ of low rectal cancer patients having undergone this technique experience local recurrence after surgery and prognosis in such patients still remains poor (4-6).

It is supposed that poor prognosis of low rectal carcinoma is mainly due to metastasis of lymph nodes outside of the TME field (6-8). Dissection of lateral pelvic lymph nodes is a complementary approach that can be considered as an important fact or to reduce local recurrence and extending low rectal cancer patients'survival. This hypothesis has been investigated in several studies. However, the role of lymph node dissection in terms of prolonging survival of advanced case of low rectal carcinoma is still disputed. In some studies lateral lymph node dissection (LLND) has not depicted survival benefit for low rectal cancer patients, while more recent large scale researches provided supporting evidence for the benefit of $\operatorname{LLND}(9,10)$. In the current study,it was aimed to assess disease free survival, LNR and complication rate among advanced low and middle rectal cancer patients who underwent TME and lateral lymph node dissection at Iran Cancer Institute.

\section{MATERIAL and METHODS}

The current research was a case-series study, carried out on 32 eligible patients with advanced stages of lower and mid-rectal cancer (stage 2 and 3) who were treated by 
TME plus LLND at the Iran Cancer Institute. The eligibility criteria included: All patients with stage 2 and 3 of lower and mid-rectal cancer, referring to Iran Cancer Institute from 2016 March to 2018 March who agreed to participate in our study. The exclusion criteria included: metastatic, high rectal and rectosigmoid cancers and unwillingness to participate in the study. The methodology of the study was reviewed and approved by the medical ethics committee of Tehran University of Medical Science (Approval ID: IR.TUMS.VCR.REC.1397.629-Certificate available on demand). Before the study, we assessed whether the patients were eligible to perform LLND according to physical examination, colonoscopy and abdominopelvic and thoracic computed tomography (CT) as a metastasis workup. Prior to study initiation, a written informed consent, addressing that patients could exit the study at any desired time, without negative impact on their future treatment procedure, was completed by each one of them.

In the study group, all patients received chemoradiotherapy as neoadjuvant treatment. All surgical operations were performed using standard open laparotomy with mid-line incision. In the LLND technique, bilateral extraction of para-iliac and obturator lymph nodes was performed (from iliac artery bifurcation to obturator nerve). In order to minimize post-operative complications, complete neurovascular and ureteral exploration was performed for all patients. After surgery, we counted the number of total dissected and positive lymph nodes to estimate LNR. All study participants were actively followed-up for 1 year after surgery and in each post-op examination, we looked for local recurrence, sexual and urinary disorders and death.

Chi-Square test was used to assess the distribution of clinical outcomes by sex. We also reported mean and standard deviation (SD) for continuous investigated variables. Additionally, to calculate disease-free survival in patients with advanced low and middle rectal cancer, Breslow (Generalized Wilcoxon) test was used in Kaplan-Meier approach. All statistical analyses were performed by $\mathrm{IBM}^{\oplus} \mathrm{SPSS}^{\odot}$ (Version 22.0.0.0).

\section{RESULTS}

Overall, the current study investigated 32 patients with advanced low and middle rectal cancer treated with TME plus LLND at the Iran Cancer Institute, of whom 17 were males and 15 were females. Mean age of the participants was 57.3 ( \pm 13.9) years. Total numbers of dissected lateral lymph nodes by TME and LLND were 279 and 232, respectively. Of the 279 dissected lymph nodes by TME, 42 nodes (in mesorectal) and of the 232 dissected lymph nodes by LLND, seven nodes (in iliac, para-iliac and obturator) were positive for metastasis (Table 1).

In the first year following surgery, for each studied patient, carcinoembryonic antigen (CEA) level was screened every three months. At the end of the first year, colonoscopy and double-contrast thoraco-abdomino-pelvic CT scan was performed on all of the studied patients. In general, lymph node
Table 1. Characteristics of the study participants $(n=32)$

\begin{tabular}{|l|l|}
\hline $\begin{array}{l}\text { Sex } \\
\text { Male }\end{array}$ & $17(53.1 \%)$ \\
Female & $15(46.8 \%)$ \\
\hline Age & \\
$\quad$ Mean (SD) & $57.3(13.9)$ \\
\hline $\begin{array}{l}\text { Total number of dissected lymphnode } \\
\text { TME }\end{array}$ & 279 \\
LLND & 232 \\
Mean (per patient) & 15.97 \\
\hline $\begin{array}{l}\text { Total number of positive lymph node } \\
\text { TME }\end{array}$ & $42(15.0 \%)$ \\
LLND & $7(3.0 \%)$ \\
Mean (per patient) & 1.53 \\
\hline
\end{tabular}

SD: Standard deviation, TME: Total mesorectal excision, LLND: Lateral lymph node dissection.

dissection associated complications was observed in one male patient with impotency. Respective number was 0 in females $(p=0.910)$. Higher local recurrence was observed in men (three patients) compared to women (one patient) which was not statistically significant ( $p=0.878)$. We also observed higher 1-year disease free survival rate in women (93.3\%) compared to men (82.4\%), which again, was not statistically significant $(p=0.356)$. In addition, 1-year disease free survival was calculated for patients with negative and positive lateral lymph nodes. 1-year disease free survival rate in patient with negative lymph nodes was $95.5 \%$ while respective number in patients with positive lymph nodes was $70 \%(p=0.047)$ (Figure 1$)$. Neither any unexpected bleeding during surgery nor any post-op hematoma or urinary complications were observed in participants.

\section{DISCUSSION}

Lateral pelvic lymphadenectomy is one of the treatments for patients suffering from advanced low rectal cancer. However, a universal agreement about its effectiveness is still lacking and there is no global agreement on whether lymph node dissection could be beneficial for low rectal cancer patients or not. Therefore, different approaches to such patients are used among surgeons worldwide. For instance, lateral pelvic lymphadenectomy is being used as arecommended treatment in Japan, while it is not frequently performed in western societies (6,11-13).

In the current study, we found tan estimated $12.5 \%$ for local recurrence in participants, which is consistent with previous studies reporting local recurrence rate in patients who had total mesorectal excision ranging from $5 \%$ to $40 \%(4,14-17)$. Yokoyama et al. have reported local recurrence in $3.0 \%$ of patients with LLND, while in patients without lymphadenectomy, it was $12.2 \%$ (18).

The percentage of 1-year disease free survival for patients treated by TME and LLND and was $87.5 \%$ in our study. Although this 


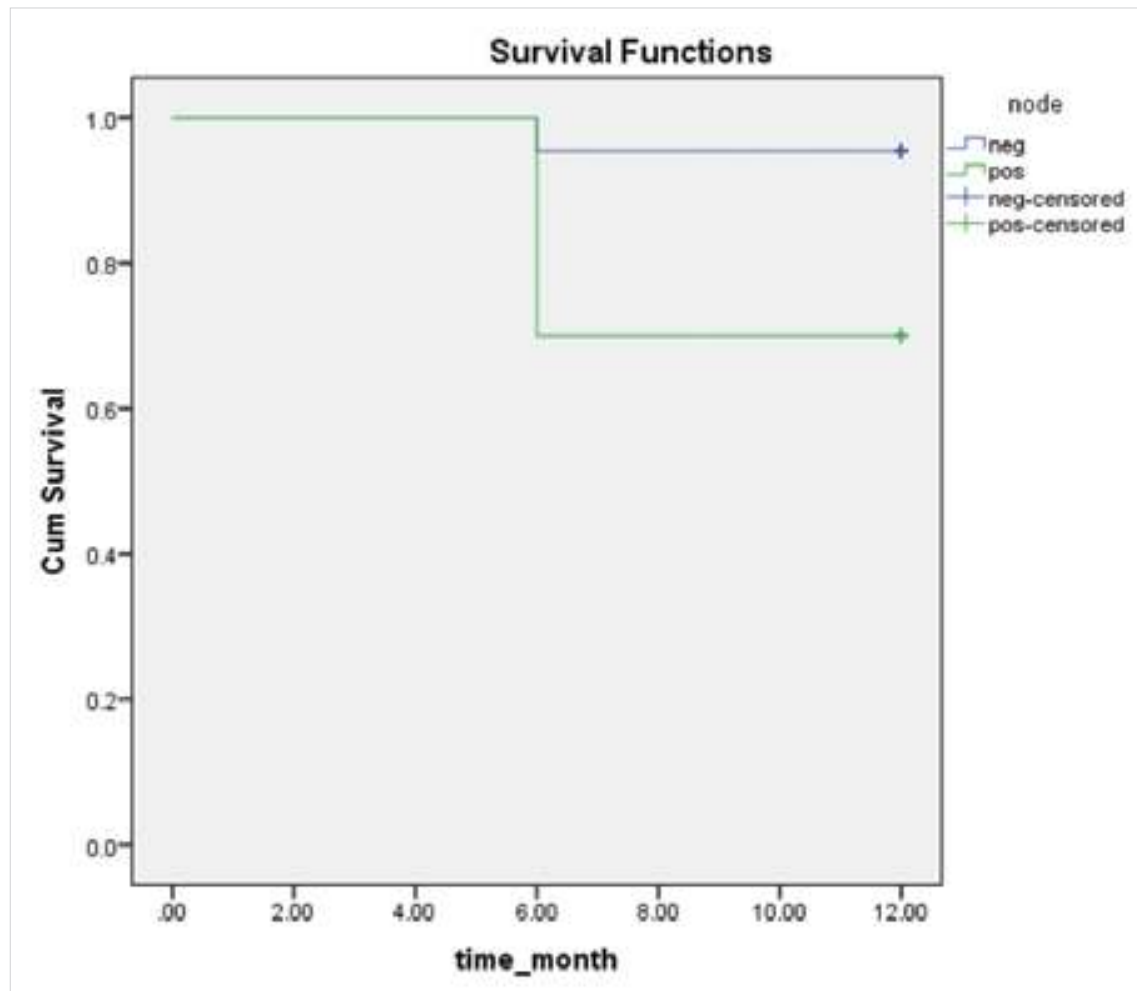

Figure 1. Disease-free survival rate of patients with advanced low rectal carcinoma admitted at Iran Cancer Institute by lymph node involvement.

number was partially higher in women than men, no statistically significant difference was observed. This finding is consistent with previously performed studies as well (19-21).

We examined 232 lateral lymph nodes, seven of which were positive for metastasis (3.0\%). This findingis substantially lower compared to the previous studies, reporting lateral pelvic lymph node involvement from $38.0 \%$ to $71 \%$. This could be the result of neoadjuvant chemoradiotherapy all of the studied patients received prior to surgery. We were unable to find any other attributable factors to the low number of positive lymph nodes in our cases. Therefore, this finding needs further testing in future studies. In addition, in recent studies, lateral lymph node (LLN) involvement rate has been reported $14.6 \%$ and $19.1 \%$ (Wu and Yokoyama), which is closer to our results $(6,18)$. Positive LLN is associated with increased risk of local recurrence, which consequently reduces survival in advanced low rectal cancer patients (6). There is some evidence indicating that LLND provides better outcomes regarding both local recurrence and survival in patients diagnosed with negative lateral pelvic lymph nodes $(6,7,18,19)$. Sugihara et al. have reported a significant difference in 5-year survival rate after surgery in patients with negative and positive lymph node dissection (7). Our current study also showed asignificantly higher 1 -year disease free survival rate in negative lymph node patients (95.5\%) compared to patients with positive LLN (70\%), which is compatible with previous studies $(7,8)$.
Lymph node dissection is not a procedure without complication. It generally increases operation time and blood loss. Hence, patient selection for LLND must be regarded as an important factor to receive better results in terms of both local recurrence and survival rate in low rectal cancer patients (18).

We encountered some limitations in our study which should be considered while interpreting the results. First of all, small number of study participants along with short follow-up time might have resulted in overestimated survival rates in patients who had TME + LLND. Secondly, as the current study was a case-series, there was no comparison group. Therefore, we believe that the findings of this study should be reevaluated in future clinical trials, as there are alternative treatments for advanced low rectal cancer including mere TME and preoperative chemoradiotherapy.

In conclusion, it seems that TME with LLND could prolong survival and reduce local recurrence in patients with advanced mid and low rectal cancer as the results of current study support the effectiveness of lymphadenectomy in terms of survival improvement of mid and low rectal cancer patients.

\section{ACKNOWLEDGEMENT}

This study was supported by the Cancer Research Center of Iran Cancer Institute. The authors would like to thank all study participants and all of our colleagues at the Iran Cancer Institute who helped us in data collection. 
Ethics Committee Approval: The methodology of the study was reviewed and approved by the medical ethics committee of Tehran University of Medical Science (Approval ID: IR.TUMS.VCR.REC.1397.629-Certificate available on demand).

Informed Consent: Written informed consent was obtained from patient who participated in this case.

Peer-review: Externally peer-reviewed.

Author Contributions: Concept - H.M.; Design - H.M., A.B.; Supervision - H.M., R.O.; Materials - A.B.; Data Collection and/or Processing - A.B., M.A.B.; Analysis and/or Interpretation - A.B.; Literature Search - M.A.B.; Writing Manuscript - A.B.; Critical Reviews - R.O., H.M.

Conflict of Interest: No conflict of interest was declared by the authors.

Financial Disclosure: The authors declared that this study has received no financial support.

\section{REFERENCES}

1. Laurent C, Nobili S, Rullier A, Vendrely V, Saric J, Rullier E. Efforts to improve local control in rectal cancer compromise survival by the potential morbidity of optimal mesorectal excision. J Am Coll Surg 2006; 203 (5): 684-91. [CrossRef]

2. Liang Y, Qing S, Ding W, Chen P, Huang Y, Yu H. Total mesorectal excision versus conventional radical surgery for rectal cancer: a meta analysis. Zhonghua Wei Chang Wai Ke Za Zhi 2007; 10 (1): 43-8. [CrossRef]

3. Szynglarewicz B, Matkowski R, Forgacz J, Pudelko M, Smorag Z, Dryl J, et al. Clinical factors in prediction of prognosis after anterior resection with total mesorectal excision for carcinoma of the rectum. Oncol Rep 2007; 17 (2): 471-5. [CrossRef]

4. Piso P, Dahlke MH, Mirena P, Schmidt U, Aselmann H, Schlitt HJ, et al. Total mesorectal excision for middle and lower rectal cancer: a single institution experience with 337 consecutive patients. J Surg Oncol 2004; 86 (3): 115-21. [CrossRef]

5. Lezoche E, Guerrieri M, De Sanctis A, Campagnacci R, Baldarelli M, Lezoche $G$, et al. Long-term results of laparoscopic versus open colorectal resections for cancer in 235 patients with a minimum follow-up of 5 years. Surg Endosc 2006; 20 (4): 546-53. [CrossRef]

6. Wu ZY, Wan J, Li JH, Zhao G, Yao Y, Du JL, et al. Prognostic value of lateral lymph node metastasis for advanced low rectal cancer. World J Gastroenterol 2007; 13 (45): 6048. [CrossRef]

7. Sugihara K, KobayashiH, Kato T, Mori T, Mochizuki H, Kameoka S, et al. Indication and benefit of pelvic sidewall dissection for rectal cancer. Dis Colon Rectum 2006; 49 (11): 1663-72. [CrossRef]
8. Shimomura M, Ikeda S, Takakura Y, Kawaguchi Y, Tokunaga M, Egi $H$, et al. Adequate lymph node examination is essential to ensure the prognostic value of the lymph node ratio in patients with stage III COlorectal cancer. Surg Today 2011; 41 (10): 1370. [CrossRef]

9. Kobayashi H, Mochizuki H, Kato T, Mori T, Kameoka S, Shirouzu K, et al. Outcomes of surgery alone for lower rectal cancer with and without pelvic sidewall dissection. Dis Colon Rectum 2009; 52 (4): 567-76. [CrossRef]

10. AkiyoshiT, Watanabe T, Miyata S, Kotake K, Muto T, Sugihara K. Results of a Japanese nationwide multi-institutional study on lateral pelvic lymph node metastasis in low rectal cancer: is it regional or distant disease? Ann Surg 2012; 255 (6): 1129-34. [CrossRef]

11. Koch M, Kienle P, Antolovic D, Büchler MW, Weitz J. Is the lateral lymph node compartment relevant? Rectal Cancer Treatment: Springer; 2005. pp. 40-5. [CrossRef]

12. Kusunoki $M$, Inoue Y. Current surgical management of rectal cancer. Dig Surg 2007; 24 (2): 115-9. [CrossRef]

13. Matsuoka H, Masaki T, Sugiyama M, Atomi Y. Impact of lateral pelvic lymph node dissection on evacuatory and urinary functions following low anterior resection for advanced rectal carcinoma. Langenbecks Arch Surg 2005; 390 (6): 517-22. [CrossRef]

14. Radice E, Dozois R. Locally recurrent rectal cancer. Dig Surg 2001; 18 (5): 355-62. [CrossRef]

15. Maslekar S, Sharma A, Macdonald A, Gunn J, Monson J, Hartley J. Do supervised colorectal trainees differ from consultants in terms of quality of TME surgery? Colorectal Dis 2006; 8 (9): 790-4. [CrossRef]

16. Rengan R, Paty PB, Wong WD, Guillem JG, Weiser M, Temple L, et al. Ten-year results of preoperative radiation followed by sphincter preservation for rectal cancer: increased local failure rate in nonresponders. Clin Col Cancer 2006; 5 (6): 413-21. [CrossRef]

17. Hohenberger W, Merkel S, Matzel K, Bittorf B, Papadopoulos T, Göhl J. The influence of abdomino-peranal (intersphincteric) resection of lower third rectal carcinoma on the rates of sphincter preservation and locoregional recurrence. Colorectal Dis 2006; 8 (1):23-33. [CrossRef]

18. Yokoyama S, Takifuji K, Hotta T, Matsuda K, Watanabe T, Mitani Y, et al. Survival benefit of lateral lymph node dissection according to the region of involvement and the number of lateral lymph nodes involved. Surg Today 2014; 44 (6): 1097-103. [CrossRef]

19. Ueno M, Oya M, Azekura K, Yamaguchi T, Muto T. Incidence and prognostic significance of lateral lymph node metastasis in patients with advanced low rectal cancer. Br J Surg 2005; 92 (6): 756-63. [CrossRef]

20. Wichmann M, Müller C, Hornung H, Lau-Werner U, Schildberg F. Gender differences in long-term survival of patients with colorectal cancer. Br J Surg 2001; 88 (8): 1092-8. [CrossRef]

21. McArdle C, McMillan D, Hole D. Male gender adversely affects survival following surgery for colorectal cancer. Br J Surg 2003; 90 (6): 711-5. [CrossRef] 


\section{OLGU SERISI-ÖZET}

Turk J Surg 2020; 36 (2): 224-228

\section{Rektum kanseri hastalarında lateral lenf nodu diseksiyonunun terapötik sonuçlarının, lenf nodu oranının ve kısa-uzun dönem komplikasyonlarının değerlendirilmesi}

Habibollah Mahmoodzadeh ${ }^{1}$, Ramesh Omranipour ${ }^{1}$, Anahita Borjian ${ }^{1}$, Mohammad Amin Borjian

${ }^{1}$ Tahran Tıp Bilimleri Üniversitesi, Kanser Enstitüsü, Tahran, İran

\section{ÖZET}

Giriş ve Amaç: Bu çalışmanın amacı, 2016-2018 yılları arasında İran Kanser Enstitüsünde total mezorektal eksizyon (TME) ve lateral lenf nodu diseksiyonu (LLND) geçiren ileri evre orta-alt rektum kanseri hastalarında (2-3. Evre) hastalıksız sağkalım, lenf nodu oranı (LNO) ve komplikasyon oranını değerlendirmektir.

Gereç ve Yöntem: Bu çalışma Mart 2016-Mart 2018 tarihleri arasında İran Kanser Enstitüsünde küratif cerrahi ve lateral lenf nodu diseksiyonu ile tedavi edilen 32 hasta üzerinde yürütüldü. Cinsiyete göre ikili klinik sonuçların dağıııını değerlendirmek için ki-kare testi kullanıldı. Ayrıca, \%95 güven aralıklarına karşııık gelen bir yıllık hastalıksız sağkalımı hesaplamak için Kaplan-Meier yaklaşımında Breslow testi kullanıldı.

Bulgular: TME ile diseke edilen 279 lenf nodundan 42 (mezorektal)'si ve LLND ile diseke edilen 232 lenf nodundan yedisi (iliyak, para-iliyak ve obturator) metastaz için pozitif tespit edilmiştir. Kadınlara oranla (bir hasta) erkeklerde (üç hasta) daha yüksek oranda lokal nüks izlenmiş ancak bu oran istatistiksel açıdan anlamlı bulunmamıştır $(p=0,878)$. Yine istatistiksel olarak anlamlı olmasa da erkeklere kıyasla kadınlarda daha yüksek bir yıllık hastalıksız sağkalım oranı tespit edilmiştir (erkekler: \%82,4, kadınlar: \%93,3, $p=0,356$ ). Negatif lenf nodu olan hastada bir yıllık hastalıksız sağkalım oranı \%95.5 iken aynı oran pozitif lenf nodu olan hastalarda \%70 idi $(p=0,047)$.

Sonuç: LLND ile TME, ileri evre alt rektum kanseri hastalarında lokal nüksü azaltabilir ve sağkalımı uzatabilir. Ancak, bu tür bir müdahaleyi İran'da standart tedavi olarak kabul etmek için büyük ölçekli klinik çalışmalara ihtiyaç vardır.

Anahtar Kelimeler: Rektal neoplazma, lenf nodu eksizyonu, sağkalım, kemoradyoterapi

Doi: $10.5578 /$ turkjsurg.4593 